\title{
The general specifications of the MEDITS surveys*
}

\author{
JACQUES A. BERTRAND ${ }^{1}$, LUIS GIL DE SOLA², COSTAS PAPACONSTANTINOU ${ }^{3}$, \\ GIULIO RELINI ${ }^{4}$ and ARNAULD SOUPLET ${ }^{5}$
}

\begin{abstract}
${ }^{1}$ IFREMER, Rue de l'île d'Yeu, BP 21105, 44311 Nantes cedex 03, France, e-mail: bertrand@ifremer.fr
${ }^{2}$ IEO, Puerto pesquero s/n, Apto 285, 29640 Fuengirola, Spain, e-mail: gildesola@ma.ieo.es

${ }^{3}$ NCMR, Aghios Kosmas Hellinikion, 16644 Athens, Greece, e-mail: pap@ posidon.ncmr.gr

${ }^{4}$ SIBM / Dip.Te.Ris., Università di Genova, Via Balbi 5, 16126 Genoa, Italy, e-mail: sibmzool@unige.it

${ }_{5}^{5}$ IFREMER, Bd Jean Monnet, BP 171, 34203 Sète cedex France, e-mail: asouplet@ifremer.fr
\end{abstract}

\begin{abstract}
SUMMARY: An international bottom trawl survey was designed from a European Commission's initiative to produce biological data on the demersal resources in the Mediterranean Sea. Nine Mediterranean countries are associated in the programme, which covers all the trawlable areas along their coasts from 10 to $800 \mathrm{~m}$ depth. From 1994 to 2000, one survey was carried out each year, applying common standardized protocols. Seven yearly surveys have therefore been done, with a total of 7,500 stations prospected. This paper presents the methods adopted to carry out the surveys.
\end{abstract}

Key words: trawl survey, Mediterranean Sea, trawl gear

\section{INTRODUCTION}

The Mediterranean Sea is a complex biogeographic system including a large variety of specific areas. Due to the small extension of the continental shelf in most of the areas, benthic and demersal resources are mainly exploited close to the shore. As most of the benthic and demersal fish stocks are defined and exploited at a national level, and as exploitation is strongly distributed in a wide number of units (type of vessels, fishing techniques, landing ports, species caught, etc.), very little global information was, at the start of the programme, available on the status of these fisheries resources.

In some Mediterranean areas, national programmes of bottom trawl surveys were carried out routinely since the early eighties (Liorzou et al.,

*Received January 16, 2001. Accepted April 2, 2001.
1989; Relini, 2000). All these programmes were designed with protocols defined at local level.

The MEDITS survey programme intended to produce basic information on benthic and demersal species in terms of population distribution as well as demographic structure, on the continental shelves and along the upper slopes at a global scale in the Mediterranean. The programme began with only four partner countries (Spain, France, Italy and Greece). Nevertheless, the intention was to organize the protocols in such a way as to easily permit the enlargement of the programme to other Mediterranean countries.

So, when the partners decided to organize the MEDITS survey, one of the main challenges of the project was the adoption of common standardized sampling protocols. The basic protocols have been adopted by the four first partners early in 1994, just before the first survey. These protocols included 
TABLE 1. - The MEDITS Steering Committee.

\begin{tabular}{|c|c|}
\hline Area (clockwise) & Name (and period) \\
\hline $\begin{array}{l}\text { CC, general co-ordinator } \\
\text { CC, Spanish and Morrocan area } \\
\text { CC, French area } \\
\text { CC, Italian, Albanian, Croatian, Slovenian and Maltese areas } \\
\text { CC, Greek area }\end{array}$ & $\begin{array}{l}\text { Jacques A. BERTRAND, IFREMER France }(1994-1999) \\
\text { Arnauld SouPLET, IFREMER France }(2000) \\
\text { Giulio RELINI, SIBM/Dip.Te.Ris Italy }(2001<) \\
\text { Luis GIL DE SOLA, IEO Spain }(1994<) \\
\text { Arnauld SoUPLET, IFREMER France }(1994<) \\
\text { Giulio RELINI, SIBM/Dip.Te.Ris Italy }(1994<) \\
\text { Costas PAPACONSTANTINOU, NCMR Greece }(1994<)\end{array}$ \\
\hline $\begin{array}{l}\text { South Alboran Sea } \\
\text { Ligurian Sea, North and Central Tyrrhenian Sea (M1) } \\
\text { Sardinia (M2) } \\
\text { South Tyrrhenian Sea and Sicilian Channel (M3) } \\
\text { Sicilian Channel (Maltese area) } \\
\text { West Ionian Sea South Adriatic Sea (M4) } \\
\text { North and Central Adriatic Sea (M5) } \\
\text { North-East Adriatic Sea (Slovenian area) }\end{array}$ & $\begin{array}{l}\text { Ali Srairi, INRH Morroco }(1999<) \\
\text { Gianni ARDIZZONE, DBAU Italy }(1994<) \\
\text { Angelo CAU, DBAE Italy }(1994<) \\
\text { Dino LEVI, IRMA-CNR Italy }(1994<) \\
\text { Matthew CAMILLIERI, MAF-DFA-NAC Malta }(2000<) \\
\text { Giovanni MARANO, LBMB Italy }(1994<) \\
\text { Corrado PICCINETTI, LBMP Italy }(1994<) \\
\text { Stanko CERVE, NIB Slovenia }(1996-1998) \\
\text { Bojan MARCETA NIB Slovenia }(1998<)\end{array}$ \\
\hline $\begin{array}{l}\text { Central-East Adriatic Sea (Croatian area) } \\
\text { South-East Adriatic Sea (Albanian area) }\end{array}$ & $\begin{array}{l}\text { Stjepan JUKIC-PELADIC, IOR Croatia }(1996<) \\
\text { Alexander FLLOKO, MAF Albania }(1996-1998) \\
\text { Kastriot OSMANI, IKP-FSA Albania }(1998<)\end{array}$ \\
\hline $\begin{array}{l}\text { Argosaronic Gulf and East Ionian Sea (G2) } \\
\text { North Aegean Sea (G1) } \\
\text { South Aegean Sea (G3) }\end{array}$ & $\begin{array}{l}\text { Chrissi-Yianna POLITOU, NCMR Greece }(1995<) \\
\text { Argyris KALLIANOTIS, IFR Greece }(1996<) \\
\text { Argyris KALLIANOTIS, IMBC Greece }(1994-1996) \\
\text { Georgios TSERPES, IMBC Greece }(1996<)\end{array}$ \\
\hline Trawl technology & $\begin{array}{l}\text { Pierre-Yves DREMIÈRE, IFREMER France }(1994<) \\
\text { Loris FIORENTINI, IRPEM-CNR Italy }(1994-1998) \\
\text { Giulio COSIMI, IRPEM-CNR Italy }(1999<)\end{array}$ \\
\hline
\end{tabular}

CC: Co-ordination Committee; <: outstanding

the design of the survey, the sampling gear (feature and handling), the information collected, and the management of the data as far as the production of common standardized analyses of the data. Before the first survey, all the common protocols were brought together in a "Manual of protocols" agreed by the Steering Committee of the programme (Table 1), distributed to the participants before the first survey (1994), and published later (Anon., 1998) to ensure its distribution. This manual has been established from different experiences, and particularly from that of the IBTS Group (ICES, 1992). The protocols have been amended when necessary for the following surveys, and particularly in 1995 to take into account the experience gained during the first survey.

A first publication describing the MEDITS surveys was done a few years ago (Bertrand et al., 2000a). This paper intends to outline the main specifications of the programme and to present its evolution since 1998.

\section{Study area}

The MEDITs programme aims to conduct co-ordinated surveys from bottom trawling in the Mediterranean Sea. So far, the surveys cover all the trawlable areas over the shelves and the upper slopes from 10 to $800 \mathrm{~m}$ depth in the sampled area.
The working zone is defined as the totality of the trawlable areas off the coasts of the partner countries (Fig. 1) from 10 to $800 \mathrm{~m}$ depth. These limits have been adopted to cover at best the distribution areas of the main exploited - or potentially exploitable species, considering the administrative and technical constraints of the project. The first two surveys (1994 and 1995) have been conducted only along the coasts of Spain, France, Italy and Greece. In 1996 the area was enlarged to cover almost all the Adriatic Sea (including Slovenian, Croatian and Albanian waters). The south of the Alborán Sea has been included in the survey programme since 1999 (the Moroccan contribution), and the waters around Malta were surveyed in 2000.

The stations have been distributed applying a stratified sampling scheme with random drawing inside each stratum. The stratification parameter adopted was the depth, with the following bathymetric limits: 10, 50, 100, 200, 500 and $800 \mathrm{~m}$ (Fig. 1). Each position has been selected randomly in small sub-areas defined to get a compromise between the constraints of statistics based on random sampling and those of geostatistics (Green, 1979; Hilborn and Walters, 1992).

The foreseen average sampling rate was one station per 60 square nautical miles in all the areas except in the Adriatic where it was laid down to one 


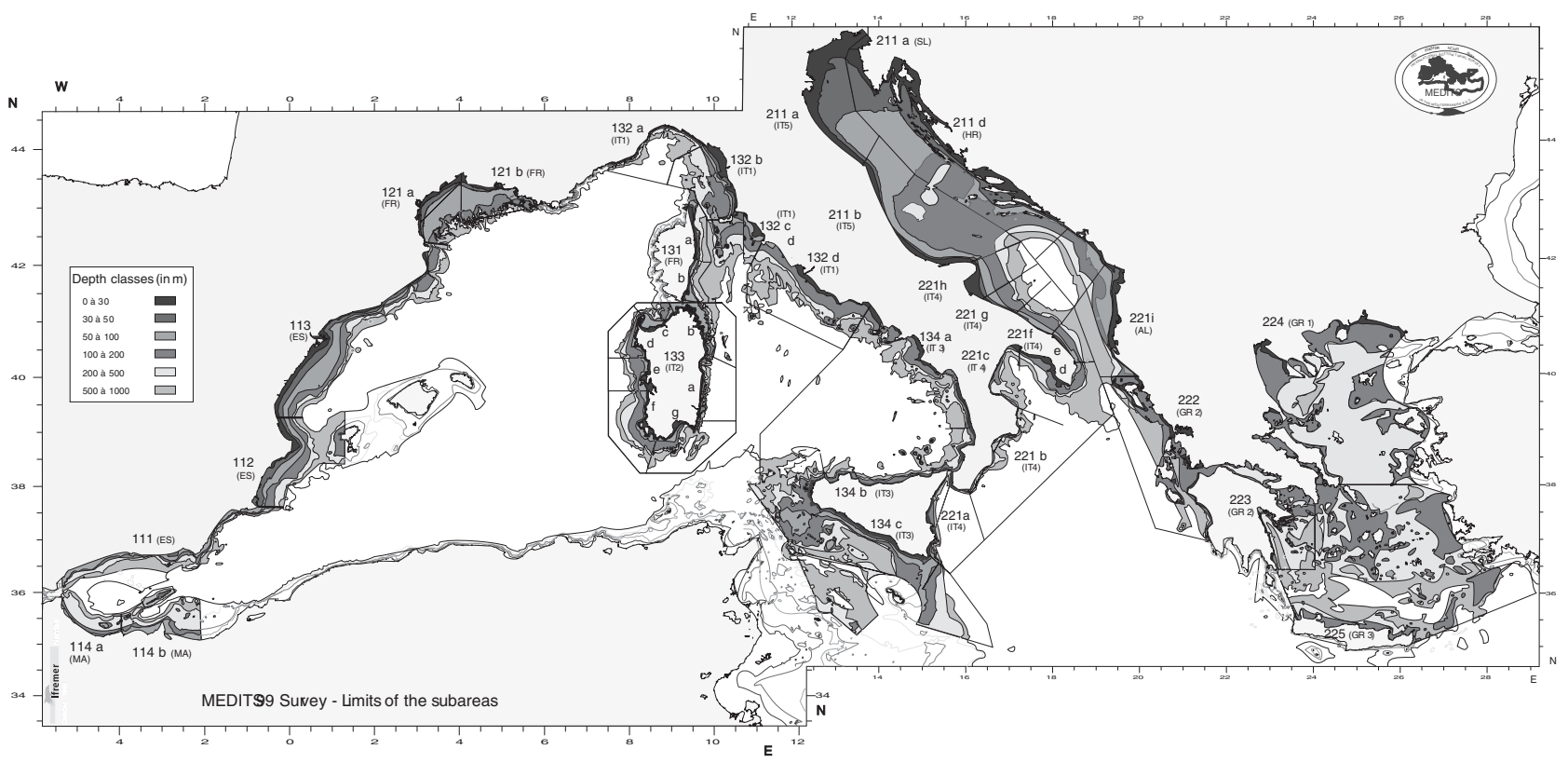

Fig. 1.- Study area of the MEDITS trawl surveys. Limits of the sampling strata (MEDITS 1999).

station per 200 square nautical miles because of the relative monotony of the depth. The same positions were visited each year. A total of about one thousand hauls was carried out during each annual survey (Table 2). Taking into account the total trawlable surface of the area $\left(504,000 \mathrm{~km}^{2}\right.$ in 1999) and the surface swept during each haul, the average ratio of surface sampled by survey is about $0.026 \%$ (Table 3 ).

\section{Sampling gear}

At the beginning of the project, it was decided that the same sampling gear should be used through- out the study by all teams. The standard device is a bottom trawl, including all the material and its rigging from the doors to the codend of the net. The chosen gear (GOC 73) is a bottom trawl (Fiorentini et al., 1999) designed for experimental fishing with scientific purpose. It achieves a compromise between different constraints. In particular, the characteristics of this gear make it usable over the depth range and in the various conditions encountered in the whole survey area. To increase the catch of demersal species, it has a vertical opening slightly superior to the most common professional gears used in the area. Its codend mesh size is $20 \mathrm{~mm}$ (stretched mesh).

TABLE 2. - Number of hauls carried out by area during the MEDITS 1994 to 2000 surveys.

\begin{tabular}{|c|c|c|c|c|c|c|c|}
\hline Area (clockwise) & 1994 & 1995 & 1996 & 1997 & 1998 & 1999 & 2000 \\
\hline Morroco (MA) & & & & & & 62 & 55 \\
\hline Spain (ES) & 83 & 111 & 107 & 102 & 94 & 117 & 114 \\
\hline France (FR) - F1 & 70 & 68 & 65 & 76 & 71 & 66 & 68 \\
\hline France (FR) - F2 & 22 & 22 & 24 & 13 & 24 & 25 & 24 \\
\hline Italy (IT) - M1 & 153 & 153 & 153 & 153 & 153 & 153 & 153 \\
\hline Italy (IT) - M2 & 123 & 108 & 125 & 126 & 123 & 124 & 123 \\
\hline Italy (IT) - M3 & 140 & 142 & 141 & 141 & 141 & 141 & 141 \\
\hline Malte (ML) & & & & & & & 5 \\
\hline Italy (IT) - M4 & 146 & 146 & 146 & 146 & 146 & 146 & 146 \\
\hline Italy (IT) - M5 & 86 & 86 & 85 & 86 & 86 & 84 & 85 \\
\hline Slovenia (SL) & & 2 & 2 & 2 & 2 & 2 & 2 \\
\hline Croatia (HR) & & & 50 & 51 & 50 & & 48 \\
\hline Albania (AL) & & & 40 & 40 & 40 & 40 & 40 \\
\hline Greece (GR) - G2 & 23 & 31 & 41 & 40 & 53 & 53 & 31 \\
\hline Greece (GR) - G1 & 44 & 43 & 64 & 64 & 64 & 64 & 65 \\
\hline Greece (GR) - G3 & 43 & 46 & 52 & 60 & 61 & 61 & 55 \\
\hline Total & 933 & 958 & 1095 & 1100 & 1108 & 1138 & 1155 \\
\hline
\end{tabular}


TABLE 3. - MEDITS 1999: Sampling scheme on the different strata, with indication (within each area and depth stratum) of the trawlable surface area $\left(\mathrm{km}^{2}\right)$, number of hauls and sampling rate (percentage of the trawlable area sampled). Location of areas is shown in Fig. 1.

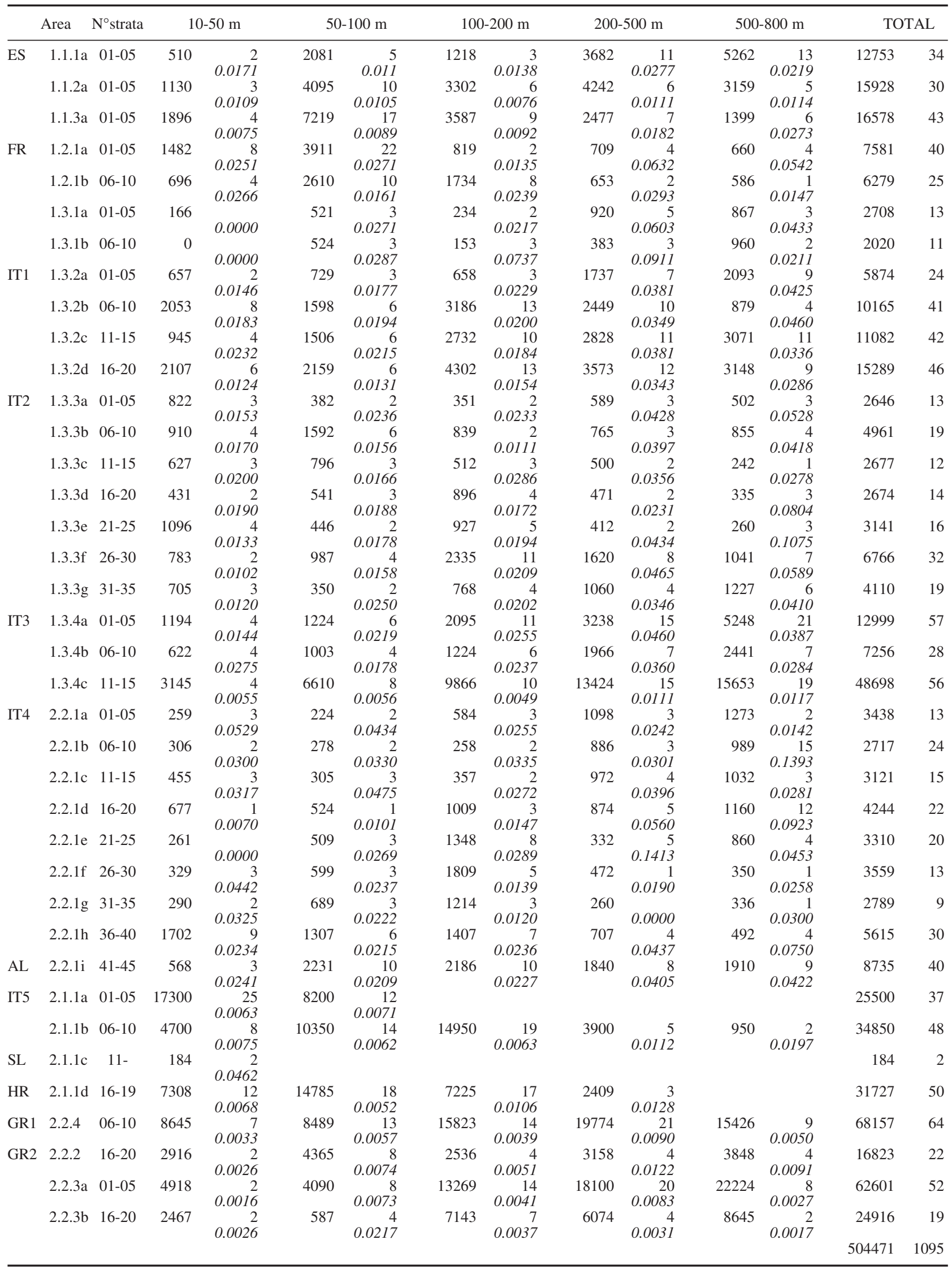


The design of the gear has been drawn up by fishery technologists (P.Y. Dremière, IFREMER-Sète) from specifications defined by the biologists. The gear has been tested from a model in a flume tank then in real conditions at sea, before its production for the first survey. Then, specific studies have been conducted to complete the knowledge about the efficiency of the gear (Dremière et al., 1999; Fiorentini et al., 1996; Fiorentini and Dremière, 1996; Fiorentini et al., 1999). When necessary the sampling gear and its handling have been slightly modified to improve its performances, especially to better stabilize it when contacting the bottom. The modifications have been decided as much as possible to limit their effects on the series consistency, but improving their quality. The main improvements were applied just before the 1995 survey (Fiorentini et al., 1999). At that time, the results of the first survey had shown that the contact of the gear with the bottom was not fully satisfactory, especially along the slopes (depths of over $200 \mathrm{~m}$ ). To improve this contact, buoyancy at the headline was reduced, links between the net and footrope were shortened, the sweeps were reduced, and rules for hauling were modified. As a secondary consequence, the vertical opening of the gear has been reduced (from an average of 3 to $2.5 \mathrm{~m}$ ), and the average wide opening enlarged consequently. Further, the tickler chain was removed in 1995 over the slopes, and everywhere in 1996.

A device to follow the geometry of the gear was systematically used only aboard some of the sampling vessels since the beginning of the survey series. Aboard the other vessels, only preliminary tests were conducted with this kind of device at the beginning of the first surveys. Since the 1998 survey, an autonomous recorder was systematically added

TABLE 4. - Codes and usual names of the species included in the MEDITS reference list.

\begin{tabular}{|c|c|c|c|}
\hline Species & Year $^{1}$ & MEDITS Code & Usual name \\
\hline Aspitrigla cuculus (Linnaeus, 1758) & $1998<$ & ASPI CUC & Red gurnard \\
\hline Citharus linguatula (Linnaeus, 1758) & $1994<$ & CITH MAC & Spotted flounder \\
\hline Eutrigla gurnardus (Linnaeus, 1758) & $1994<$ & EUTR GUR & Grey gurnard \\
\hline Galeus melastomus Rafinesque, 1809 & $1998<$ & GALU MEL & Blackmouth catshark \\
\hline Helicolenus dactylopterus (Delaroche, 1809) & $1994<$ & HELI DAC & Rockfish \\
\hline Lepidorhombus boscii (Risso, 1810) & $1994<$ & LEPM BOS & Four-spotted megrim \\
\hline Lophius budegassa Spinola, 1807 & $1994<$ & LOPH BUD & Black-bellied angler \\
\hline Lophius piscatorius Linnaeus, 1758 & $1994<$ & LOPH PIS & Angler \\
\hline Merluccius merluccius (Linnaeus, 1758) & $1994<$ & MERL MER & European hake \\
\hline Micromesistius poutassou (Risso, 1826) & $1994<$ & MICM POU & Blue whiting \\
\hline Mullus barbatus Linnaeus, 1758 & $1994<$ & MULL BAR & Red mullet \\
\hline Mullus surmuletus Linnaeus, 1758 & $1994<$ & MULL SUR & Striped red mullet \\
\hline Pagellus acarne (Risso, 1826) & $1994<$ & PAGE ACA & Axillary seabream \\
\hline Pagellus bogaraveo (Brünnich, 1768) & $1994<$ & PAGE BOG & Blackspot seabream \\
\hline Pagellus erythrinus (Linnaeus, 1758) & $1994<$ & PAGE ERY & Common pandora \\
\hline Pagrus pagrus pagrus (Linnaeus, 1758 ) & $>1996$ & SPAR PAG & Common seabream \\
\hline Phycis blennoides (Brünnich, 1768) & $1994<$ & PHYI BLE & Greater forkbeard \\
\hline Raja clavata Linnaeus, 1758 & $1994<$ & RAJA CLA & Thornback ray \\
\hline Scyliorhinus canicula (Linnaeus, 1758) & $1998<$ & SCYO CAN & Smallspotted catshark \\
\hline Solea vulgaris Quensel, 1806 & $1994<$ & SOLE VUL & Common sole \\
\hline Spicara flexuosa Rafinesque, 1810 & $1994<$ & SPIC FLE & Picarel \\
\hline Spicara smaris (Linnaeus, 1758) & $1998<$ & SPIC SMA & Picarel \\
\hline Trachurus mediterraneus (Steindachner, 1863) & $1994<$ & TRAC MED & Mediterranean horse mackerel \\
\hline Trachurus trachurus (Linnaeus, 1758) & $1994<$ & TRAC TRA & Atlantic horse mackerel \\
\hline Trigloporus lastoviza (Bonnaterre, 1788) & $1998<$ & TRIP LAS & Streaked gurnard \\
\hline Trisopterus minutus capelanus (Lacepède, 1800) & $1994<$ & TRIS CAP & Poor-cod \\
\hline Zeus faber Linnaeus, 1758 & $1994<$ & ZEUS FAB & John dory \\
\hline Aristaeomorpha foliacea (Risso, 1827) & $1994<$ & ARIS FOL & Giant red shrimp \\
\hline Aristeus antennatus (Risso, 1816) & $1994<$ & ARIT ANT & Blue and red shrimp \\
\hline Nephrops norvegicus (Linnaeus, 1758) & $1994<$ & NEPR NOR & Norway lobster \\
\hline Parapenaeus longirostris (Lucas, 1846) & $1994<$ & PAPE LON & Deep-water pink shrimp \\
\hline Eledone cirrhosa (Lamarck, 1798) & $1994<$ & ELED CIR & Horned octopus \\
\hline Eledone moschata (Lamarck, 1799) & $1997<$ & ELED MOS & Musky octopus \\
\hline Illex coindetii (Verany, 1839) & $1994<$ & ILLE COI & Broadtail squid \\
\hline Loligo vulgaris Lamarck, 1798 & $1994<$ & LOLI VUL & European squid \\
\hline Octopus vulgaris Cuvier, 1797 & $1994<$ & OCTO VUL & Common octopus \\
\hline Sepia officinalis Linnaeus, 1758 & $1994<$ & SEPI OFF & Common cuttlefish \\
\hline
\end{tabular}

${ }_{1}$ Year at which the species was introduced $(<)$ or eliminated $(>)$.

Ref. Usual names for fish : Fischer W., M.L. Bauchot, M. Schneider (rédacteurs), 1987. Fiches FAO d'identification des espèces pour les besoins de la pêche (Révision 1). Méditerranée et Mer Noire Zone de pêche 37. Rome, FAO, vol 1 et 2 , 1530 p. 
along the headline aboard all the vessels to record water temperature at the beginning and end of hauls. The device used (Vemco Minilog) also recorded depth all during the hauls. A first analysis of the gear trajectory described from these recordings (Bertrand et al., 2002) has shown that some progress is yet to be done to better standardize the distance really swept by the gear at the deepest locations.

\section{Target species and data collected}

A list of common target species (including fish, molluscs and crustaceans) was established with reference to their commercial production, their accessibility to a bottom trawl and their potential interest as biological indicators in the different areas. The reference list of species defined at the beginning of the programme included thirty species. It was enlarged to thirty-six species during the following years (Table 4), taking into account the removal of one species (Sparus pagrus) from the list in 1996 due to its very rare occurrence in the samples. Observations on these species are the total number of individuals, total weight, length frequency distribution, and sex (including sexual maturity stage). The characteris- tics of each kind of observation are specified in the manual of protocols (Anon., 1998). For all the other species of commercial interest (fish, crustaceans and molluscs), the total number and total weight are reported for each haul. During each annual survey, a total of approximately 150 species were identified aboard each vessel.

The data are put in computer files by the teams in charge of the survey. Four standard exchange formats (in ASCII) including normalized coding are defined (Table 5). A specific software was written (Souplet, 1996a,b) for an automatic checking of the data. This checking is done by each of the partners for their own data before their regrouping. After a second validation in the regrouping phase (at IFREMER-Sète), copies of the total set of data files are deposited on CD-ROM at the co-ordinator's and EC-DG Fish offices. The process is managed such as to make the data bank available a few months after the end of each survey (usually in October).

\section{Work at sea}

Since 1994, one survey has been carried out every year, during the spring and the beginning of

Table 5. - Parameters included in the exchange files.

\begin{tabular}{|c|c|c|}
\hline Haul characteristics (file A) & Catch per haul (file B) & Biological parameters (file C) \\
\hline $\begin{array}{l}\text { Country } \\
\text { Vessel } \\
\text { Gear } \\
\text { Rigging } \\
\text { Doors } \\
\text { Year } \\
\text { Month } \\
\text { Day } \\
\text { Haul number } \\
\text { Codend closing device } \\
\text { Shooting time } \\
\text { Shooting quadrant } \\
\text { Shooting latitude } \\
\text { Shooting longitude } \\
\text { Shooting depth } \\
\text { Hauling time } \\
\text { Hauling quadrant } \\
\text { Hauling latitude } \\
\text { Hauling longitude } \\
\text { Hauling depth } \\
\text { Haul duration } \\
\text { Validity code } \\
\text { Course (rectilinear or not) } \\
\text { Species reporting code } \\
\text { Distance } \\
\text { Vertical opening } \\
\text { Wing opening } \\
\text { Briddles length } \\
\text { Warp length } \\
\text { Warp diameter } \\
\text { Hydrological station number } \\
\text { Observations }\end{array}$ & $\begin{array}{l}\text { Country } \\
\text { Vessel } \\
\text { Year } \\
\text { Haul number } \\
\text { Codend closing device } \\
\text { Part of the codend } \\
\text { Faunistic category } \\
\text { Species code (Rubbin type) } \\
\text { Total weigth in the haul } \\
\text { Total number in the haul } \\
\text { Females Number } \\
\text { Males number } \\
\text { Unsexed number }\end{array}$ & $\begin{array}{l}\text { Country } \\
\text { Vessel } \\
\text { Year } \\
\text { Haul number } \\
\text { Codend closing device } \\
\text { Part of the codend } \\
\text { Faunistic category } \\
\text { Species code (Rubbin type) } \\
\text { Length class code } \\
\text { Fraction weight } \\
\text { Subsample weight } \\
\text { Sex } \\
\text { Number of measured individuals } \\
\text { Length class } \\
\text { Maturity } \\
\text { Nb of individuals in that class }\end{array}$ \\
\hline
\end{tabular}


TABLE 6. - Calendar of the MEDITS surveys from 1994 to 2000.

\begin{tabular}{|c|c|c|c|c|c|c|c|c|c|c|c|c|c|c|}
\hline \multirow[t]{2}{*}{ Area } & \multicolumn{2}{|c|}{1994} & \multicolumn{2}{|c|}{1995} & \multicolumn{2}{|c|}{1996} & \multicolumn{2}{|c|}{1997} & \multicolumn{2}{|c|}{1998} & \multicolumn{2}{|c|}{1999} & \multicolumn{2}{|c|}{2000} \\
\hline & from & to & from & to & from & to & from & to & from & to & from & to & from & to \\
\hline Morroco & & & & & & & & & & & 2-June & 2-July & 20-May & 31-May \\
\hline Spain & 28-May & 20-June & 22-avr & 21-May & 2-May & 27-May & 9-May & 3-June & 3-May & 30-May & $4-\mathrm{N}$ & 3-June & 22-May & 23-June \\
\hline France & 16-Мау & 16-June & 24-June & 23-July & 28-May & 24-June & 26-Мау & 28-June & 17-May & 19-June & 6-May & 7-June & 31-Мау & 2-July \\
\hline Italy - M1 & 21-May & 1-July & 1-June & 14-July & 1-June & 22-July & 4-June & 28-July & 21-May & 28-July & 7-May & 7-July & 26-May & 22-July \\
\hline Italy - M2 & 9-June & 4-Aug & 21-May & 27-July & 17-June & 2-Aug & 23-June & 5-Aug & 25-May & 3-July & 17-May & 2-July & 29-Мау & 21-July \\
\hline Italy - M3 & 2-June & 15-July & 3-June & 10-July & 31-Мay & 5-July & 3-June & 6-July & 22-May & 27-June & 6-May & 9-June & 26-Маy & 1-July \\
\hline Italy - M4 & 3-June & 13-July & 2-June & 11-July & 4-June & 15-July & 4-June & 21-July & 8-May & 22-June & 11-May & 31-Aug & 2-May & 21-June \\
\hline Italy - M5 & 21-May & 3-June & 6-June & 30-June & 3-June & 24-June & 2-June & 22-June & 10-June & 4-July & 4-Aug & 14-Oct & 8-June & 2-Aug \\
\hline Slovenia & & & & & 16-June & 16-June & 13-June & 13-June & 22-June & 22-June & 27-Aug & 27-Aug & 7-July & 7-July \\
\hline Croatia & & & & & 15-June & 25-June & 14-June & 22-June & 22-June & 1-July & & & 26-June & 2-July \\
\hline $\begin{array}{l}\text { Albania } \\
\text { Malta }\end{array}$ & & & & & 18-July & 25-July & 24-July & 8-Aug & 24-June & 11-July & 17-Aug & 29-Aug & 22-June & 8-July \\
\hline $\begin{array}{l}\text { Malta } \\
\text { Greece - G2 }\end{array}$ & & & & & & & & & & & & & $\begin{array}{r}\text { 7-June } \\
\text { 12-June }\end{array}$ & $\begin{array}{l}\text { 8-June } \\
\text { 8-July }\end{array}$ \\
\hline Greece - G1 & $\begin{array}{l}\text { 11-Aug } \\
\text { 15-June }\end{array}$ & $\begin{array}{r}\text { 2L-Aug } \\
7 \text {-Aug }\end{array}$ & 17-May & 7-June & $\begin{array}{l}\text { lo-Jury } \\
\text { 20-June }\end{array}$ & $\begin{array}{r}\text { 3-Aug } \\
\text { 29-July }\end{array}$ & 9-June & $\begin{array}{l}\text { 14-Aug } \\
\text { 15-July }\end{array}$ & $\begin{array}{l}\text { 12-June } \\
\text { 17-June }\end{array}$ & $\begin{array}{l}\text { 10-July } \\
\text { 20-July }\end{array}$ & $\begin{array}{l}\text { 8-June } \\
\text { 18-June }\end{array}$ & $\begin{array}{r}\text { 7-July } \\
27-J u l y\end{array}$ & $\begin{array}{l}\text { 12-June } \\
\text { 21-June }\end{array}$ & 28-July \\
\hline Greece - G3 & 4-June & 12-July & 12-June & 6-July & 3-June & 4-July & 14-June & 4-Aug & 16-June & 27-July & 9-June & 21-July & 2-June & 13-July \\
\hline
\end{tabular}

summer (Table 6). To reduce the duration of each survey, several boats ( 8 to 11 vessels according to the year) work at the same time. Each of these vessels works at sea during about one month per year. Research vessels and chartered fishing vessels are used, depending on local possibilities. As much as possible, the same vessel was used every year in each area.

The duration of the hauls is fixed to 30 minutes on depths less than $200 \mathrm{~m}$ and 60 minutes on more important depths.

The organisation of the work at sea mainly depends on the facilities aboard the vessels. In some cases, the samples are only taken and preserved on board and all the biological analyses are carried out in the laboratories. On the contrary in other situations, particularly aboard the research vessels, the whole biological analysis of the samples, including the data input into computer files, are conducted on board.

\section{Access to the MEDITS data}

A specific chart defines the rules for distribution of the MEDITS data. From this chart, the full access to the raw MEDITS data bank is guaranteed to the European Commission and the laboratories participating in the surveys. This access is managed through the concerned national co-ordinators of the programme. The Co-ordination committee must be informed of projects intending to use raw data from the international data bank. Other users may freely use the aggregated data presented in the reports produced by the MEDITS group.

\section{Data analysis}

At the end of each survey, a working group gathering together scientists from the different teams involved in the survey implements standard analyses. The analyses are focused on the reference list species. They are based on the production of biomass and relative abundance indices (in $\mathrm{kg} / \mathrm{km}^{2}$ and in number of individuals $/ \mathrm{km}^{2}$ ) as well as length frequency distributions by species and strata. These analyses are made using statistical methods approved by the Steering Committee, and included in a specific software (Souplet, 1996a,b). Basic results are presented on standardized media (tables, figures and maps), including visualization of interannual variations. The results obtained by these working groups are distributed in annual survey reports.

Furthermore, specific results obtained from the programme have been presented during an international symposium held in Pisa in 1998 (Bertrand and Relini, 2000). This symposium was mainly devoted to communications related to the properties of the fishing gear and regional approaches on biology and ecology of the species encountered during the surveys, including multispecies approaches. These works gave very useful basic information on the scope of the available data and on ways to enlarge the knowledge of demersal resources in the Mediterranean from these data. They have drawn attention to the very wide variety and variability of situations encountered and the care requested for elaboration of general diagnoses on the present status concerning the demersal resources in the Mediterranean Sea. This scope may include analyses devoted to 
critical development stages such as recruitment (Bertrand et al., 2000), or focused on groups of species subject to fishing impact and potentially in danger, such as elasmobranchs (Bertrand et al., 2000b). Furthermore, they may contribute to knowledge on the relationships between demersal species dynamics and their environment, including natural and human constraints. Progress in that direction will often require the combination of data from different sources. We may anticipate that the organization of the MEDITs data bank will favour such work. Different research programmes have already integrated this information. The papers presented in this volume, and the references given in its appendix (Abelló et al., 2002), provide a general idea of the domains which have been investigated, to date, with the support of the MEDITS data.

\section{CONCLUSION}

The Medits data bank has been built thanks to a very intense collaboration between a number of regional teams who had the best knowledge on the biology of demersal species in the different areas. The quality of the data bank is strongly linked to their adherence to the protocols, and the quality of the biological information included. The quantitative data quality is directly linked with precision in handling the sampling gear and reporting information related to its filtering power and motions. The present experience shows that this goal may be obtained only from a strong collaboration between biologists and technologists. More generally, the success of such a long-term survey programme would require implementation of a quality assurance approach to ensure the quality in data collection and the best level of consistency in the series.

The utility of such a survey programme as support for fishery management is strongly related to its ability to produce indices able to characterize the diversity of situations in the whole area and their variations and trends in time. So far, its first goal is the production of relative abundance indices and demographic structure of the main exploited species. Further, the programme offers a fantastic opportunity for complementary observations and studies related to biology and ecology of the demersal species and communities.

Development of easy-to-use instrumentation may facilitate data collection. Nevertheless, in its present configuration, we may consider that the MEDITS data bank is still under-utilized. Furthermore, as explained for other bottom trawl survey series (Heessen et al., 2000; Walsh and McCallum, 1995), more extensive analyses of the data would help to identify certain errors and inconsistencies. In addition, these investigations would be very useful to improve the quality of the data and the overall efficiency of the survey programme.

\section{ACKNOWLEDGEMENTS}

The MediTs programme is conducted thanks to the financial support of the European Commission (Directorate for Fisheries) jointly with the contribution of the partner countries.

\section{REFERENCES}

Abelló, P., J. Bertrand, L. Gil de Sola, C. Papaconstantinou, G. Relini and A. Souplet (eds.). - 2002. Marine demersal resources of the Mediterranean: the MEDITS International trawl survey (1994-1999). Sci. Mar., 66 (Suppl. 2).

Anon. - 1998. Campagne internationale de chalutage démersal en Méditerranée (MEDITS): manuel des protocoles. Biol. Mar. Medit., 5 (2): 515-572.

Bertrand, J., L. Gil de Sola, C. Papaconstantinou, G. Relini and A. Souplet. - 2000. Distribution of juveniles of some demersal species in the northern Mediterranean. Biol. Mar. Medit., 7(3): 81-97.

Bertrand, J.A., L. Gil de Sola, C. Papaconstantinou, G. Relini and A. Souplet. - 2000a. An international bottom trawl survey in the Mediterranean: the MEDITS programme. In: J.A. Bertrand and G. Relini (eds.), Demersal resources in the Mediterranean, Proceedings of the Symposium held in Pisa, 18-21 March 1998, pp. 76-93. Actes de Colloques, 26. IFREMER, Plouzané.

Bertrand, J., L. Gil de Sola, C. Papaconstantinou, G. Relini and A. Souplet. -2000 b. Contribution on the distribution of elasmobranchs in the Mediterranean (from the MEDITS surveys). Biol. Mar. Medit., 7(1): 1-15.

Bertrand, J.A., I. Leonori, P.Y. Dremière and G. Cosimi. - 2002. Depth trajectory and performance of a trawl used for an international bottom trawl survey in the Mediterranean. Sci. Mar., 66 (Suppl. 2): 169-182.

Bertrand, J.A. and G. Relini (eds.).- 2000. Demersal resources in the Mediterranean. Actes de Colloques, 26. IFREMER, Plouzané.

Dremière, P.-Y., L. Fiorentini, G. Cosimi, I. Leonori, A. Sala and A. Spagnolo. - 1999. Escapement from the main body of the bottom trawl used for the Mediterranean international trawl survey (MEDITS). Aquat. Living Resour., 12(3): 207-217.

Fiorentini, L., G. Cosimi, A. Sala, V. Palumbo and I. Leonori. 1996. Intercalibration des campagnes internationales de chalutage démersal en Méditerranée centrale. IRPEM. CE Med/93/015: 59 p.

Fiorentini, L. and P.Y. Dremière. - 1996. Efficacy and selectivity of the trawl used for the MEDITS project. IRPEM: $17 \mathrm{p}$.

Fiorentini, L., P.-Y. Dremière, I. Leonori, A. Sala and V. Palumbo. - 1999. Efficiency of the bottom trawl used for the Mediterranean international trawl survey (MEDITS). Aquat. Living Resour., 12 (3): 187-205.

Green, R.H. - 1979. Sampling design and statistical methods for biologists. John Wiley \& Sons, New York

Heessen, H.J.L., J. Dalskov and R.M. Cook. - 2000. The international Bottom Trawl Survey in the North Sea, Skagerrak and Kattegat: a history of one of the "ancestors" of MEDITS. In: J.A. Bertrand and G. Relini (eds.), Demersal resources in the 
Mediterranean, pp. 13-36. Actes de Colloques, 6. IFREMER, Plouzané.

Hilborn, R. and C.J. Walters. - 1992. Quantitative Fisheries Stock Assessment: Choice, Dynamics Uncertainty. Chapman \& Hall, London.

ICES. - 1992. Manual for the International Bottom trawl Surveys. Revision IV. ICES/CIEM: $47 \mathrm{p}$.

Liorzou, B., A. Campillo and J.L. Bigot. - 1989. Estimation de l'abondance relative de Lophius budegassa du golfe du Lion à partir de campagnes expérimentales de 1983 à 1987. Bull Soc. zool. de France, 114(4): 101-112.

Relini, G. - 2000. Demersal trawl surveys in Italian seas: a short review. In: J.A. Bertrand and G. Relini (eds.), Demersal resources in the Mediterranean, pp. 46-75. Actes de Colloqucs,
26. IFREMER, Plouzané.

Souplet, A. - 1996a. Calculation of abundance indices and length frequencies in the MEDITS survey. In: J. Bertrand (ed.), Campagne internationale de chalutage démersal en Méditerranée (MEDITS). Campagne $1995 \mathrm{Vol}$. III. Rapport final de contrat CEEIFREMER-IEO-SIBM-NCMR (MED/93/020,018,006,004).

Souplet, A. - 1996b. Checkmed: a software to check the MEDITs data files. In: J. Bertrand (ed.), Campagne internationale de chalutage démersal en Méditerranée (MEDITS). Campagne 1995 Vol. I, pp. 21-26. Rapport final de contrat CEEIFREMER-IEO-SIBM-NCMR (MED/93/020,018,006,004).

Walsh, S.J. and B.R. McCallum. - 1995. Survey trawl mensuration using acoustic trawl instrumentation. ICES CM 1995/B:26: 1-20. 